\title{
Thyroid hormone metabolism may depend on dietary fat ${ }^{*}$
}

\author{
K. Lachowicz ${ }^{1}$ I. Koszela-Piotrowska ${ }^{2}$ and D. Rosolowska-Huszcz ${ }^{1,3}$ \\ ${ }^{1}$ Warsaw University of Life Sciences, Faculty of Human Nutrition and Consumer Sciences, \\ Department of Dietetics \\ Nowoursynowska 159c, 02-776 Warsaw, Poland \\ ${ }^{2}$ Nencki Institute of Experimental Biology, Department of Cellular Biochemistry \\ Pasteura 3, 02-093 Warsaw, Poland
}

(Received 16 August 2007; revised version 17 November 2007; accepted 15 January 2008)

\begin{abstract}
The effect of dietary fat level and composition on the activities of enzymes involved in thyroid hormone metabolism: thyroid peroxidase (TPO) and hepatic type I deiodinase (DI) were investigated. Male Wistar rats weighing on average $277 \mathrm{~g}(\mathrm{SEM}=4.23 \mathrm{~g})$ received different levels $(\mathrm{w} / \mathrm{w}$ $5 \%$-LF, 10\%-MF, 20\%-HF) and types of dietary fat (sunflower oil - group S, rape seed oil - R and palm oil - P) over a three weeks. TPO rose with fat intake in group R and declined in groups $\mathrm{S}$ and P. Hepatic DI activity was not affected by dietary fat composition, but was influenced by fat level, decreasing as fat intake increased. The influences of dietary fat level and composition on thyroid physiology are interdependent. TPO and DI activity seem to respond in a differentiated manner to changes in the amount and type of fatty acids consumed.
\end{abstract}

KEY WORDS: iodothyronine deiodinase, thyroid peroxidase, nutrition, liver, fatty acids, rat

\section{INTRODUCTION}

Thyroid hormones regulate lipid metabolism, influencing fatty acid (FA) synthesis (Blennemann et al., 1992) and oxidation (Jackson-Hayes et al., 2003), lipolysis (Germack et al., 1996), cellular uptake of cholesterol and transformation into bile acids (Ness and Lopez, 1995). A reciprocal influence of FA on thyroid

\footnotetext{
${ }^{*}$ Supported by the State Committee for Scientific Research, Grant No. 5P06G02517

${ }^{3}$ Corresponding author: e-mail: danuta_rosolowska_huszcz@sggw.pl
} 
activity has been demonstrated at several points of the thyroidal axis (HPT) and thyroid hormone (TH) metabolism. The first effect identified was displacement of TH by FA from plasma binding proteins (Hollander, 1967). Further studies corroborated competition between FA and TH in binding plasma proteins (Lim et al., 1995) and nuclear receptors (THR) (Yamamoto et al., 2001). FA have been also shown to influence THR number and activity (Bonilla et al., 2001). Effects of dietary fat on plasma TH levels (Takeuchi et al., 1995), TSH secretion (Clandinin et al., 1998), thyroid peroxidase (TPO) activity (Rosołowska-Huszcz et al., 2001; Skufca et al., 2003) and hepatic iodothyronine deiodinase (DI) activity (Kahl et al., 1998) have been also found.

Thyroid peroxidase is a key enzyme in TH biosynthesis catalysing iodide oxidation, iodination of thyrosine residues of thyroglobulin and coupling of iodothyronines (Dunn and Dunn, 2001). Hepatic DI catalyses both outer and inner ring iodothyronine deiodination yielding metabolically active $\mathrm{T}_{3}$ and inactive reverse triiodothyronine ( $\mathrm{rT}_{3}$ ) (Bianco et al., 2002).

Knowledge concerning the influence of dietary fat on thyroid activity could assist in the development of nutritional recommendations useful in the treatment of not only thyroid disorders but also in the prevention and treatment of atherosclerosis and obesity. The aim of this study was to investigate the impact of dietary fat composition and amount on the activities of key enzymes involved in thyroid hormone metabolism, TPO and DI.

\section{MATERIAL AND METHODS}

\section{Experimental design}

Male Wistar rats $(\mathrm{n}=54)$ of average weight $277 \mathrm{~g}$ (SEM $4.23 \mathrm{~g})$ were obtained from the animal husbandry facility at the Medical Research Center of the Polish Academy of Sciences (Warsaw, Poland). The animals were divided into groups (6 rats each) fed on diets differing in fat composition (sunflower oil - group $\mathrm{S}$, rape seed oil - group R, palm oil - group P) and level (w/w): 5\% - low fat diets (LF), 10\% - medium fat (MF), 20\% - high fat (HF). Diet compositions are given in Table 1 and the fatty acid content of dietary fats is shown in Table 2. The animals were housed individually in standard conditions. Feed and water were given ad libitum. After 3 weeks the rats were sacrificed and blood was collected by cardiac puncture. The thyroid and liver were excised, weighed, immediately frozen in liquid nitrogen and held at $-80^{\circ} \mathrm{C}$ prior to further analysis. All procedures were approved by the Local Animal Care and Use Committee in Warsaw. 
Table 1. Composition of experimental diets (Gronowska-Senger and Pierzynowska, 2002)

\begin{tabular}{|c|c|c|c|}
\hline \multirow{2}{*}{ Components $\quad$ Diets } & Low fat & Medium fat & High fat \\
\hline & \multicolumn{3}{|c|}{ g per $100 \mathrm{~g} \mathrm{~S}, \mathrm{R}$ and $\mathrm{P}$ diets $^{4}$} \\
\hline Wheat starch & 68 & 63 & 53 \\
\hline Casein & 18 & 18 & 18 \\
\hline Fat $^{1}$ & 5 & 10 & 20 \\
\hline Potato starch & 5 & 5 & 5 \\
\hline Vitamin mixture $^{2}$ & 1 & 1 & 1 \\
\hline Mineral mixture ${ }^{3}$ & 3 & 3 & 3 \\
\hline Choline chloride & 0.2 & 0.2 & 0.2 \\
\hline
\end{tabular}

${ }^{1}$ sunflower, rape seed and palm oils were used

${ }^{2}$ vitamin mixture composition per 100 g of mixture; IU: vit. A, 200 000; vit. $\mathrm{D}_{3}, 20000$; vit. E, 1000; mg: vit. K 50; g: PABA 1, inosytol 1, niacin 0.4, calcium pantothenate 0.4 ; mg: riboflavin 80 , thiamin chloride 50 , pyridoxine chloride 50 , biotin 4 , vit. $\mathrm{B}_{12}, 0.3$

${ }^{3}$ mineral mixture composition, per $100 \mathrm{~g}$ of mixture; g: $\mathrm{CaHPO}_{4} 73.5, \mathrm{~K}_{2} \mathrm{HPO} 8.1, \mathrm{~K}_{2} \mathrm{SO}_{4} 6.8, \mathrm{NaCl}$ 3.06, $\mathrm{CaCO}_{3} 2.1, \mathrm{Na}_{2} \mathrm{HPO}_{4} 2.14, \mathrm{MgO} 2.5, \mathrm{mg}_{2} \mathrm{C}_{3} \mathrm{H}_{4}(\mathrm{OH})(\mathrm{COO})_{2} \mathrm{Fe} 558, \mathrm{ZnCO}_{3} 81, \mathrm{MnCO}_{3} 421$, $\mathrm{CuCO}_{3} 33, \mathrm{C}_{3} \mathrm{H}_{4}(\mathrm{OH})(\mathrm{COOH})_{3} 706 ; \mu \mathrm{g} \mathrm{KJ} 720$

${ }^{4} \mathrm{~S}$ - sunflower oil diet; $\mathrm{R}$ - rape seed oil diet; $\mathrm{P}$ - palm oil diet

Table 2. Content of fatty acids in dietary fats, $\mathrm{g}$ per $100 \mathrm{~g}$ fat

\begin{tabular}{lccc}
\hline Fatty acids & Sunflower oil & Rape seed oil & Palm oil \\
\hline C16:0 & 6.03 & 5.44 & 47.24 \\
C18:0 & 3.40 & 1.19 & 2.65 \\
C18:1 n-9 & 22.18 & 62.31 & 36.08 \\
C18:2 n-6 & 65.91 & 25.16 & 4.07 \\
C18:3 n-3 & 0.40 & 5.36 & 0.00 \\
\hline
\end{tabular}

\section{Chemical analysis}

Thyroid peroxidase activity was determined in a thyroidal microsomal fraction as described previously (Rosołowska-Huszcz et al., 2001). Iodothyronine deiodinase activity was measured in a liver microsomal fraction according to Nauman et al. (1984) with $\mathrm{T}_{4}$ as a substrate. $\mathrm{T}_{3}-\mathrm{I}^{125}$ (spec. activity $1.2 \mu \mathrm{Ci} / \mu \mathrm{g}$ ) was obtained from Orion laboratories (Hungary).

Protein content were determined by the method of Lowry et al. (1951) with bovine serum albumin as a standard.

Free fatty acid (palmitic - C16:0, stearic - C18:0, oleinic - C18:1 n-9, linoleic - C18:2 n-6, linolenic - C18:3 n-3, arachidonic - 20:4 n-6, docosahexanoic - 22:6 $\mathrm{n}-3)$ concentrations in plasma were determined by HPLC according to Puttmann (1993). Triacyloglicerol (TAG) plasma concentration was estimated using a kit from Sigma (Cat. No T2449) and total cholesterol using a kit from Analco (Cat. No F400 VR) (Warsaw, Poland). Fatty acid content in dietary fats was determined by gas chromatography (Precht and Molkentin, 1995). 


\section{Statistical analysis}

The data were analysed using two-way analysis of variance. Significant differences between means at the level $\mathrm{P}=0.05$ were followed by post hoc least significant difference test (LSD). Correlations were estimated by calculation of the Pearson correlation coefficient. Statistica 6.0 software was used.

\section{RESULTS}

Dietary fat level significantly influenced body weight gain only in groups $\mathrm{S}$ and $\mathrm{R}$ (Table 3). Body weight gain was directly related to the intake of fat $(\mathrm{r}=0.51$, $\mathrm{P}<0.001)$, PUFA $(\mathrm{r}=0.68, \mathrm{P}<0.0001)$ and $\mathrm{C} 18: 2(\mathrm{r}=0.68, \mathrm{P}<0.0001)$. Daily feed intake expressed in $g$ per day was influenced neither by fat level nor its composition (Table 3). Efficiency of feed energy (body weight gain divided by energy intake) depended both on the type $(\mathrm{P}<0.000002)$ and amount $(\mathrm{P}<0.04)$ of dietary fat (Table 3 ). The profile of fatty acid intake was highly differentiated between groups (Table 4).

Table 3. Body weight gain (BWG), feed intake (FI) and efficiency of feed energy (FE) for rats fed diets containing $5(\mathrm{LF}), 10(\mathrm{MF})$ or $20 \%(\mathrm{HF})(\mathrm{w} / \mathrm{w})$ of sunflower $(\mathrm{S})$, rape seed $(\mathrm{R})$ or palm $(\mathrm{P})$ oil for three weeks. Values expressed as the mean with standard error for six animals

\begin{tabular}{|c|c|c|c|c|c|c|c|}
\hline \multirow{3}{*}{ Variables } & \multirow{3}{*}{ Diets $^{1}$} & \multicolumn{6}{|c|}{ Dietary groups $^{2}$} \\
\hline & & \multicolumn{2}{|c|}{$\mathrm{S}$} & \multicolumn{2}{|c|}{$\mathrm{R}$} & \multicolumn{2}{|c|}{$\mathrm{P}$} \\
\hline & & mean & SEM & mean & SEM & mean & SEM \\
\hline \multirow{3}{*}{$\begin{array}{l}\text { BWG } \\
\text { g/day }\end{array}$} & $\mathrm{LF}$ & $3.69^{\mathrm{aB}}$ & 0.21 & $3.03^{\mathrm{a}}$ & 0.21 & $2.71^{\mathrm{A}}$ & 0.31 \\
\hline & MF & $3.72^{\mathrm{a}}$ & 0.27 & 3.44 & 0.16 & 3.00 & 0.30 \\
\hline & $\mathrm{HF}$ & $4.98^{\mathrm{bB}}$ & 0.45 & $3.90^{\mathrm{bA}}$ & 0.29 & $3.36^{\mathrm{A}}$ & 0.14 \\
\hline \multirow{3}{*}{$\begin{array}{l}\text { FI } \\
\text { g/day }\end{array}$} & $\mathrm{LF}$ & 22.52 & 0.40 & 21.79 & 0.46 & 22.94 & 0.50 \\
\hline & MF & 22.90 & 0.52 & 20.89 & 0.66 & 22.23 & 0.82 \\
\hline & $\mathrm{HF}$ & 21.84 & 0.69 & 21.45 & 0.59 & 20.35 & 0.83 \\
\hline \multirow{3}{*}{$\begin{array}{l}\text { FE } \\
\text { g BWG/ } 1 \mathrm{~kJ}\end{array}$} & LF & $10.98^{\mathrm{B}}$ & 0.46 & $9.01^{\mathrm{A}}$ & 0.51 & $7.85^{\mathrm{A}}$ & 0.81 \\
\hline & MF & $9.99^{\mathrm{a}}$ & 0.53 & $10.23^{\mathrm{B}}$ & 0.78 & $8.38^{\mathrm{A}}$ & 0.74 \\
\hline & $\mathrm{HF}$ & $12.62^{\mathrm{bB}}$ & 1.12 & $9.94^{\mathrm{A}}$ & 0.31 & $9.14^{\mathrm{A}}$ & 0.49 \\
\hline
\end{tabular}

different $^{\mathrm{a}, \mathrm{b}, \mathrm{c}}$ letters indicate significant differences within groups $\mathrm{S}, \mathrm{R}$ or $\mathrm{P}(\mathrm{P}<0.05)$; different ${ }^{\mathrm{A}, \mathrm{B}, \mathrm{C}}$ letters indicate significant differences between groups $\mathrm{S}, \mathrm{R}$ and $\mathrm{P}(\mathrm{P}<0.05)$

1,2 explanations see Table 1

Dietary fat composition significantly affected plasma concentrations of C16:0, C18:0, C18:1 and C18:2. Plasma cholesterol and TAG concentrations were influenced neither by fat level nor its composition (Table 5). 
Table 4. Intake of FA, mg/day /100 g of final body weight

\begin{tabular}{|c|c|c|c|c|c|c|c|}
\hline \multirow{3}{*}{ Variables } & \multirow{3}{*}{ Diets $^{1}$} & \multicolumn{6}{|c|}{ Dietary groups $^{2}$} \\
\hline & & \multicolumn{2}{|c|}{$\mathrm{S}$} & \multicolumn{2}{|c|}{$\mathrm{R}$} & \multicolumn{2}{|c|}{$\mathrm{P}$} \\
\hline & & mean & SEM & mean & SEM & mean & SEM \\
\hline \multirow{3}{*}{ C16:0 } & LF & $18.1^{\mathrm{aA}}$ & 0.3 & $15.5^{\mathrm{aA}}$ & 0.2 & $158.9^{\mathrm{aB}}$ & 4.0 \\
\hline & MF & $39.2^{\mathrm{aA}}$ & 0.1 & $31.7^{\mathrm{aA}}$ & 1.0 & $296.7^{\mathrm{bB}}$ & 10.0 \\
\hline & $\mathrm{HF}$ & $64.6^{\mathrm{bA}}$ & 2.4 & $60.0^{\mathrm{bA}}$ & 1.7 & $498.2^{\mathrm{cB}}$ & 19.4 \\
\hline \multirow{3}{*}{ C18:0 } & $\mathrm{LF}$ & $10.2^{\mathrm{aB}}$ & 0.2 & $3.4^{\mathrm{aA}}$ & 0.0 & $8.9^{\mathrm{aB}}$ & 0.2 \\
\hline & MF & $22.1^{\mathrm{bC}}$ & 0.2 & $6.9^{\mathrm{bA}}$ & 0.2 & $16.6^{\mathrm{bB}}$ & 0.6 \\
\hline & $\mathrm{HF}$ & $36.4^{\mathrm{cC}}$ & 1.3 & $13.1^{\mathrm{cA}}$ & 0.4 & $27.9^{\mathrm{cB}}$ & 10.9 \\
\hline \multirow{3}{*}{ C18:1 } & LF & $66.4^{\mathrm{aA}}$ & 1.0 & $177.3^{\mathrm{aC}}$ & 2.2 & $121.4^{\mathrm{aB}}$ & 3.0 \\
\hline & MF & $144.0^{\mathrm{bA}}$ & 1.3 & $362.6^{\mathrm{bC}}$ & 11.1 & $226.6^{\mathrm{bB}}$ & 7.7 \\
\hline & $\mathrm{HF}$ & $237.6^{\mathrm{cA}}$ & 8.7 & $687.0^{\mathrm{cC}}$ & 19.4 & $380.5^{\mathrm{cB}}$ & 148.2 \\
\hline \multirow{3}{*}{ C18:2 } & $\mathrm{LF}$ & $197.5^{\mathrm{aC}}$ & 3.0 & $71.6^{\mathrm{aB}}$ & 0.9 & $13.7^{\mathrm{aA}}$ & 0.3 \\
\hline & MF & $428.0^{\mathrm{bC}}$ & 4.0 & $146.4^{\mathrm{bB}}$ & 4.5 & $25.6^{\mathrm{A}}$ & 0.9 \\
\hline & $\mathrm{HF}$ & $706.2^{\mathrm{cC}}$ & 25.9 & $277.4^{\mathrm{cB}}$ & 7.9 & $42.9^{\mathrm{bA}}$ & 1.7 \\
\hline \multirow{3}{*}{ C18:3 } & $\mathrm{LF}$ & $1.20^{\mathrm{aA}}$ & 0.02 & $15.25^{\mathrm{aB}}$ & 0.19 & 0.00 & 0.00 \\
\hline & MF & $2.60^{\mathrm{A}}$ & 0.02 & $31.19^{\mathrm{bB}}$ & 0.96 & 0.00 & 0.00 \\
\hline & $\mathrm{HF}$ & $4.29^{\mathrm{bA}}$ & 0.16 & $59.10^{\mathrm{cB}}$ & 1.67 & 0.00 & 0.00 \\
\hline
\end{tabular}

${ }^{1,2}$ explanations as for the Table 1

The effects of the level and type of fat on TPO activity (Figure 1A) were interrelated (ANOVA, effect of interaction: $\mathrm{P}<0.0001$ ). In rats fed the LF diet, TPO activity was significantly lower in groups $\mathrm{S}$ and $\mathrm{R}$ than in group $\mathrm{P}$. In rats
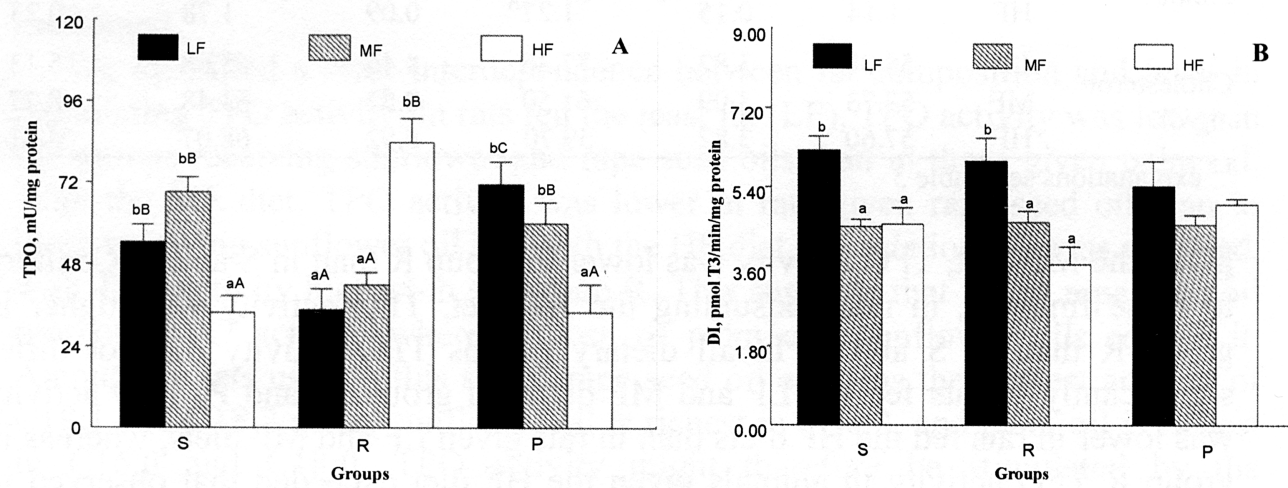

Figure 1. Thyroid peroxidase (TPO $[\mathrm{mU} / \mathrm{mgP}]$ - panel A) and iodothyronine deiodinase (DI [pmol $\mathrm{T}_{3} / \mathrm{min} /$ $\mathrm{mgP}]$ - panel B) activities in rats fed diets containing 5\% (LF), 10\% (MF) or 20\% (HF) (w/w) sunflower oil (group S), rape seed oil (group R) or palm oil (group P) for three weeks. Values are expressed as the mean with standard error for six animals. Different $a, b$ letters indicate significant differences within groups $S, R$ and $\mathrm{P}(\mathrm{P}<0.05)$; different $\mathrm{A}, \mathrm{B}$ letters indicate significant differences between groups $\mathrm{S}, \mathrm{R}$ and $\mathrm{P}(\mathrm{P}<0.05)$ 
Table 5. Plasma FA, TAG and cholesterol concentrations

\begin{tabular}{|c|c|c|c|c|c|c|c|}
\hline \multirow{3}{*}{ Variables } & \multirow{3}{*}{ Diets $^{1}$} & \multicolumn{6}{|c|}{ Dietary groups ${ }^{2}$} \\
\hline & & \multicolumn{2}{|c|}{$\mathrm{S}$} & \multicolumn{2}{|c|}{$\mathrm{R}$} & \multicolumn{2}{|c|}{$\mathrm{P}$} \\
\hline & & mean & SEM & mean & SEM & mean & SEM \\
\hline \multirow{3}{*}{$\begin{array}{l}\mathrm{C} 16: 0 \\
\mu \mathrm{mol} / 1\end{array}$} & $\mathrm{LF}$ & $179.75^{b}$ & 35.21 & 140.60 & 34.56 & $140.00^{\mathrm{a}}$ & 31.77 \\
\hline & MF & $161.67^{\mathrm{b}}$ & 24.83 & 109.50 & 10.93 & $153.40^{\mathrm{a}}$ & 36.09 \\
\hline & $\mathrm{HF}$ & $73.25^{\mathrm{aA}}$ & 14.82 & $113.75^{\mathrm{A}}$ & 6.00 & $268.60^{\mathrm{bB}}$ & 56.61 \\
\hline \multirow{3}{*}{$\begin{array}{l}\mathrm{C} 18: 0 \\
\mu \mathrm{mol} / 1\end{array}$} & $\mathrm{LF}$ & $130.75^{\mathrm{bB}}$ & 19.35 & $47.20^{\mathrm{A}}$ & 14.55 & $50.80^{\mathrm{aA}}$ & 15.59 \\
\hline & MF & $134.50^{\mathrm{bB}}$ & 21.42 & $46.83^{\mathrm{A}}$ & 10.56 & $56.00^{\mathrm{A}}$ & 9.91 \\
\hline & $\mathrm{HF}$ & $27.25^{\mathrm{aA}}$ & 4.62 & $44.25^{\mathrm{A}}$ & 13.11 & $96.40^{\mathrm{bB}}$ & 17.58 \\
\hline \multirow{3}{*}{$\begin{array}{l}\text { C18:1 } \\
\mu \mathrm{mol} / 1\end{array}$} & LF & 77.75 & 33.19 & 94.25 & 64.67 & $165.60^{\mathrm{a}}$ & 54.66 \\
\hline & MF & 87.67 & 18.49 & 202.50 & 49.76 & 243.33 & 84.01 \\
\hline & $\mathrm{HF}$ & $74.67^{\mathrm{A}}$ & 22.28 & 208.00 & 35.34 & $338.33^{\mathrm{bB}}$ & 118.64 \\
\hline \multirow{3}{*}{$\begin{array}{l}\mathrm{C} 18: 2 \\
\mu \mathrm{mol} / 1\end{array}$} & LF & 157.50 & 43.79 & 144.33 & 38.09 & 103.20 & 46.67 \\
\hline & MF & 214.50 & 38.55 & 173.67 & 46.77 & 84.20 & 28.60 \\
\hline & $\mathrm{HF}$ & 171.00 & 70.00 & 205.25 & 40.64 & 182.00 & 61.80 \\
\hline \multirow{3}{*}{$\begin{array}{l}\mathrm{C} 18: 3 \\
\mu \mathrm{mol} / 1\end{array}$} & LF & 6.25 & 0.75 & $11.17^{\mathrm{a}}$ & 3.19 & 6.00 & 3.11 \\
\hline & MF & $7.33^{\mathrm{A}}$ & 3.32 & $17.33^{\mathrm{bB}}$ & 4.61 & $1.80^{\mathrm{A}}$ & 0.37 \\
\hline & $\mathrm{HF}$ & $2.33^{\mathrm{A}}$ & 0.88 & $21.00^{\mathrm{cB}}$ & 4.18 & $5.40^{\mathrm{A}}$ & 2.25 \\
\hline \multirow{3}{*}{$\begin{array}{l}\mathrm{C} 20: 4 \\
\mu \mathrm{mol} / 1\end{array}$} & LF & 39.67 & 10.52 & 74.83 & 19.60 & 49.40 & 12.64 \\
\hline & MF & 44.17 & 6.59 & 46.83 & 7.80 & 54.20 & 13.37 \\
\hline & $\mathrm{HF}$ & 30.00 & 6.64 & $40.50^{\mathrm{A}}$ & 7.42 & 70.60 & 16.00 \\
\hline \multirow{3}{*}{$\begin{array}{l}\mathrm{C} 22: 6 \\
\mu \mathrm{mol} / 1\end{array}$} & LF & 32.00 & 2.08 & $21.00^{\mathrm{A}}$ & 5.14 & 14.20 & 2.80 \\
\hline & $\mathrm{MF}$ & 22.67 & 2.82 & 17.50 & 1.84 & 15.40 & 2.23 \\
\hline & $\mathrm{HF}$ & 6.50 & 0.64 & $16.75^{\mathrm{B}}$ & 1.25 & 22.20 & 2.27 \\
\hline \multirow{3}{*}{$\begin{array}{l}\text { TAG } \\
\mathrm{mmol} / 1\end{array}$} & LF & 1.26 & 0.11 & 1.52 & 0.16 & 1.27 & 0.16 \\
\hline & MF & 1.02 & 0.08 & 1.56 & 0.34 & 1.34 & 0.24 \\
\hline & $\mathrm{HF}$ & 1.14 & 0.15 & $1.27^{\mathrm{A}}$ & 0.09 & 1.78 & 0.23 \\
\hline \multirow{3}{*}{$\begin{array}{l}\text { Cholesterol } \\
\mathrm{mg} / \mathrm{dl}\end{array}$} & $\mathrm{LF}$ & 58.08 & 3.82 & 77.36 & 4.46 & 65.68 & 5.13 \\
\hline & $\mathrm{MF}$ & 57.73 & 3.09 & 61.50 & 8.82 & 63.48 & 8.77 \\
\hline & $\mathrm{HF}$ & 57.60 & 3.82 & 59.70 & 6.92 & 68.07 & 4.61 \\
\hline
\end{tabular}

1,2 explanations see Table 3

given the MF diet, TPO activity was lower in group R than in S and P. Contrary to these findings, in rats consuming the HF diet, TPO activity was higher in group $\mathrm{R}$ than in $\mathrm{S}$ and $\mathrm{P}$. In all dietary groups TPO activity did not differ significantly in rats fed the LF and MF diets. In groups $\mathrm{S}$ and $\mathrm{P}, \mathrm{TPO}$ activity was lower in rats fed the HF diets than in rats given LF and MF diets, whereas in group R TPO activity in animals given the HF diet exceeded that observed in those fed the LF and MF 
diets. Thyroid peroxidase activity was inversely related to plasma TAG concentrations $(\mathrm{r}=-0.30, \mathrm{P}<0.04)$.

Deiodinase activity (Figure 1B) was not significantly affected by dietary fat composition, but showed an inverse relationship to fat level $(\mathrm{P}<0.0001)$. Significantly higher DI activity was observed in groups fed the LF diet than in animals receiving MF and $\mathrm{HF}$ diets, however in groups $\mathrm{S}$ and $\mathrm{R}$ only. Deiodinase activity was directly related to carbohydrate intake $(\mathrm{r}=0.50, \mathrm{P}<0.002)$ and plasma $\mathrm{C} 22: 6$ concentration $(\mathrm{r}=0.35, \mathrm{P}<0.04)$, while it was inversely related to fat $(\mathrm{r}=-0.56$, $\mathrm{P}<0.0001), \mathrm{C} 18: 1(\mathrm{r}=-0.52, \mathrm{P}<0.001)$ and $\mathrm{C} 18: 2(\mathrm{r}=-0.38, \mathrm{P}<0.02)$ intakes.

\section{DISCUSSION}

The dietary fats used in this study, although all of plant origin, vary widely with regard to the fatty acids (saturated, monounsaturated, polyunsaturated) they contain and also in the plasma fatty acid profile they produce when consumed. Overall, body weight gain by rats was dependent on dietary fat level and composition. However, in animals fed palm oil, any differences in body weight gain between those receiving various amounts of fat did not reach statistical significance. The direct relationship between body weight gain and the intake of polyunsaturated fatty acids and linoleic acid, as well as the lower body weight gain observed in animals fed on the diet richest in saturated fatty acids, agree with the results of a similar study (Ellis et al., 2002). However, contrary to the findings of Ellis et al. (2002), and despite using similar levels of dietary fat, we observed the effect of fat composition in rats on both low and high fat diets.

Thyroid peroxidase and hepatic DI activities were found to be modulated by dietary fat. However, the effect of dietary fat on the activity of these two enzymes was shown to be different. While TPO activity was altered both by fat level and composition, DI activity depended only on the amount of fat consumed.

We identified a clear interdependence between fat composition and level in modulating TPO activity. In rats fed the least fat (LF), TPO activity was lower in the groups receiving sunflower and rape seed oils than in those given palm oil. With the MF diet, TPO activity was lower in rats given rape seed oil than in those receiving sunflower oil and with the HF diet this relationship was reversed, with TPO activity highest in subgroup R. This suggests that FA in rape seed oil promote TPO activity whereas those of palm and sunflower oils reduce it. Among the fats used in this study, rape seed oil contains the highest amount of C18:1 and C18:2 acids, sunflower oil is richest in C18:2, and palm oil is richest in C16:0 and $\mathrm{C} 18: 0$. TPO activity might therefore be stimulated by the consumption of polyunsaturated n-3 FA and/or monounsaturated n-9 C18:1, while it is reduced by saturated and polyunsaturated n-6 FA. Our results corroborate data obtained 
by others indicating stimulation of HPT axis activity by n-3 FA. A raised plasma concentration of TSH was found in rats fed diets enriched in C22:6 compared with animals on a diet supplemented with AA or a standard diet (Clandinin et al., 1998). Stimulating effects of $n-3$ polyunsaturated FA have also been observed for other elements of HPT axis activity such as transthyretin expression in the brain (Puskas et al., 2003) and thyrocyte proliferation (Makino et al., 2001). However, other results also suggest the involvement of PUFA n-6 in the stimulation of thyroid activity. The endogenous ligand of peroxisome proliferator activated receptor $\gamma($ PPAR $\gamma)$-15-deoxy- $\Delta^{12,14}-$ PGJ $_{2}\left(15 \mathrm{~d} \mathrm{PGJ}_{2}\right)$ - a product of C20:4 metabolism (Forman et al., 1995) was shown to facilitate the synthesis of thyroglobulin in a functional rat epithelial cell line (Kasai et al., 2000). Taking into consideration the similar mode of regulation of thyroglobulin and TPO gene transcription (Espinoza et al., 2001), $15 \mathrm{dPGJ}_{2}$ might represent an intermediate in the signalling pathway by which PUFA affect TPO level.

The direct relationship between DI activity and carbohydrate intake observed in our study is in accordance with the stimulation of DI expression and activity by glucose (Bianco et al., 2002). The inverse relationship between DI activity and fat intake agrees with previous results showing a decrease in 5' deiodinating DI activity in rats fed on high fat diets (Kahl et al., 1998) and an increase in plasma $\mathrm{rT}_{3}$ observed in men consuming high levels of fat (Otten et al., 1980). DI expression in the liver has an obligatory requirement for THR, either TR $\beta$ or TR $\alpha 1$ (Amma et al., 2001). Bonilla et al. (2001) found that a diet containing high levels of coconut oil (38\% w/w) decreased expression of THR in the liver. Thus, an increase in the amount of fat consumed could affect DI expression by diminishing THR stimulation. PPAR have been also shown to modulate THR activity by competing for retinoic acid RXR receptors that heterodimerize with both PPAR and $\mathrm{T}_{3}$ receptors (Miyamoto et al., 1997).

These results prompt us to conclude that the amount of fat consumed and its composition influence thyroid activity affecting thyroid hormone synthesis, and its deiodination.

\section{REFERENCES}

Amma L.L., Campos-Barros A., Wang Z., Vennström B., Forrest D., 2001. Distinct tissue-specific roles for thyroid hormone receptors $\beta$ and $\alpha 1$ in regulation of type 1 deiodinase expression. Mol. Endocrinol. 15, 467-475

Bianco A.C., Salvatore D., Gereben B., Berry M.J., Larsen P.R., 2002. Biochemistry, cellular and molecular biology and physiological roles of the iodothyronine selenodeiodinases. Endocrine Rev. 23, 38-89

Blennemann B., Monn Y.K., Freake H.C., 1992. Tissue-specific regulation of fatty acid synthesis by thyroid hormone. Endocrinology 130, 637-643

Bonilla S., Redonnet A., Noël-Suberville C., Groubet R., Pallet V., Higueret P., 2001. Effect of a pharmacological activation of PPAR on the expression of RAR and TR in rat liver. J. Physiol. Biochem. 57, 1-8 
Clandinin M.T., Claerhout D.L., Lien E.L., 1998. Docosahexaenoic acid increases thyroid-stimulating hormone concentration in male and adrenal corticotrophic hormone concentration in female weanling rats. J. Nutr. 128, 1257-1261

Dunn J.T., Dunn A.D., 2001. Update on intrathyroidal iodine metabolism. Thyroid 11, 407-414

Ellis J., Lake A., Hoover-Plow J., 2002. Monounsaturated canola oil reduces fat deposition in growing female rats fed a high or low fat diet. Nutr. Res. 22, 609-621

Espinoza C.R., Schmitt T.L., Loos U., 2001. Thyroid transcription factor 1 and Pax 8 synergistically activate the promoter of human thyroglobulin gene. J. Mol. Endocrinol. 27, 59-67

Forman B.M., Tontonoz P., Chen J., Brun R.P., Spiegelman B.M., Evans R.M., 1995. 15-deoxy-delta 12,14 - prostaglandin $\mathrm{J} 2$ is a ligand for the adipocyte determination factor PPAR gamma. Cell $83,803-812$

Germack R., Adli H., Vassay R., Perret G.Y., 1996. Triiodothyronine and amiodarone effects on $\beta_{3}$-adrenoreceptor density and lipolytic response to the $\beta_{3}$-adrenergic agonist BRL 37344 in rat white adipocytes. Fundam. Clin. Pharmacol. 10, 289-297

Gronowska-Senger A., Pierzynowska J., 2002. Biological Food Evaluation (in Polish). SGGW Press, Warszawa, pp. 10-11

Hollander C., 1967. Free fatty acids: a possible regulator of free thyroid hormone levels in man. Endocrinol. Metab. 27, 1219-1223

Jackson-Hayes L., Song S., Lavrentyev S.N., Jansen M.S., Hilgartner F.B., Tian L., Wood P.A., Cook G.A., Park E.A., 2003. A thyroid hormone response unit formed between the promoter and first intron of the carnitine palmitoylotransferase-I $\alpha$ gene mediates the liver-specific induction by thyroid hormones. J. Biol. Chem. 278, 7964-7972

Kahl S., Rosebrough R.W., Elsasser T.H., 1998. Hepatic iodothyronine 5'-monodeiodinase activity in the broiler chicken: effect of dietary fat and triiodothyronine $\left(\mathrm{T}_{3}\right)$ supplementation. Nutr. Res. 18, 1039-1047

Kasai K., Banba N., Hishinuma A., Matsumura M., Kakishita H., Matsumara M., Motohashi S., Sato N., Hattori Y., 2000. 15-deoksy-delta(12,14)-prostaglandin J(2) facilitates thyroglobulin production by cultured human thyrocytes. Amer. J. Physiol.- Cell Physiol. 276, C1859-C1869

Lim C.F., Munro S., Wynne K., Topliss D., Stockigt J., 1995. Influence of nonesterified fatty acids and lysolecithins on thyroxine binding to thyroxine-binding globulin and transthyretin. Thyroid $5,319-324$

Lowry O.H., Rosebrough N.J., Farr A.L., Randall R.J., 1951. Protein measurements with Folin phenol reagent. J. Biol. Chem. 193, 265-275

Makino N., Oda N., Miura N., Imamura S., Yamamoto K., Kato T., Fujiwara K., Sawai Y., Iwase K., Nagasaka A., Itoh M., 2001. Effect of eicosapentaenoic acid ethyl ester on hypothyroid function. J. Endocrinol. 171, 259-265

Miyamoto T., Kaneko A., Kakizawa T., Yajima H., Kamijo K., Sekine R., Hiramatsu K., Nishii Y., Hashimoto T., Hashizume K., 1997. Inhibition of peroxisome proliferator signaling pathways by thyroid hormone receptor. J. Biol. Chem. 272, 7752-7758

Nauman A., Porta S., Bardowska U., Fiedorowicz K., Sadjak A., Korsatko W., Nauman J., 1984. The effect of adrenaline pretreatment on the in vitro generation of 3,3',5-triiodothyronine and 3,3',5'-triiodothyronine (revers $T_{3}$ ) in rat liver preparation. Hormone Metab. Res. 16, 471-474

Ness G.C., Lopez D., 1995. Transcriptional regulation of rat hepatic low - density lipoprotein receptor and cholesterol $7 \alpha$ hydroxylase by thyroid hormone. Arch. Biochem. Biophys. 323, 404-408

Otten M.H., Hennemann G., Docter R., Visser T.J., 1980. The role of dietary fat in peripheral thyroid hormone metabolism. Metabolism 29, 930-935

Precht D., Molkentin J., 1995. Trans fatty acids: Implications for health, analytical methods, incidence in edible fats and intake. Nahrung 39, 343-374 
Puskas L.G., Kitajka K., Nyakas C., Barcelo-Coblijn G., Farkas T., 2003. Short-term administration of omega 3 fatty acids from fish oil results in increased transthyretin transcription in old rat hippocampus. Proc. Nat. Acad. Sci. USA 100, 1580-1585

Puttmann M., Krug H., Ochsenstein E., Kattermann R., 1993. Fast HPLC determination of serum free fatty acids in the picomole range. Clin. Chem. 39, 825-832

Rosołowska-Huszcz D., Gromadzka-Ostrowska J., Wilczak J., Romanowicz K., Borysiak M., Dębska M., Mazurek B., 2001. Thyroid peroxidase activity, hepatic glucose-6-phosphate dehydrogenase activity and corticosterone level in plasma and tissues of rats fed different dietary fats. J. Anim. Feed Sci. 10, 185-200

Skufca P., Brandsch C., Hirche F., Eder K., 2003. Effects of dietary thermally oxidized fat on morfology and mRNA concentrations of thyroidal iodide transporter and thyroid peroxidase in rats. Ann. Nutr. Metab. 47, 207-213

Takeuchi H., Matsuo T., Tokuyama K., Suzuki M., 1995. Serum triiodothyronine concentration and $\mathrm{Na}^{+}, \mathrm{K}^{+}$-ATPase activity in liver and skeletal muscle are influenced by dietary fat type in rats. J. Nutr. 125, 2364-2369

Yamamoto N., Li Q.L., Mita S., Morisawa S., Inoue A., 2001. Inhibition of thyroid hormone binding to the nuclear receptor by mobilization of free fatty acids. Hormone Metab. Res. 33, 131-137 